\title{
Transmission Grid Connection of Energy Storage Facilities - Overview and Challenges
}

\author{
Zlatko OFAK, Alan ŽUPAN, Tomislav PLAVŠIĆ
}

\begin{abstract}
Energy storage is an emerging technology that can provide flexibility for the electrical power system operation, especially in the conditions of large scale penetration of highly intermittent renewable energy sources. The paper gives an overview of energy storage technologies, giving the main technical characteristics and comparison of different energy storage features, like specific energy and power, price, number of cycles, expected lifetime, etc. Basic requirements for the connection of production and load facilities to the transmission network are described, as well as challenges regarding energy storage transmission grid integration. Finally, worldwide examples of energy storage grid connection projects are given.
\end{abstract}

Keywords: energy storage; grid connection; renewable energy sources; transmission network

\section{INTRODUCTION}

Social and political goals concerning environmental protection and stopping the negative trends of $\mathrm{CO}_{2}$ emissions have resulted with massive renewable energy sources constructions and installations in recent years. Most of them include intermittent renewable energy sources, such as wind power plants and solar power plants, which add significant uncertainty and insecurity into electrical power system operation because of their stochastic nature that before existed only on the consumption side. This uncertainty and insecurity is manifested in increased needs for flexibility sources that are able to offer necessary capacities for electrical power system balancing. Along with renewable energy sources technologies development, development of technologies that are capable to facilitate and stimulate their integration into the electrical power system is being accelerated. One of these technologies is the technology of energy storages. Although the technique of electrical energy storing is being present via pump hydro storage from the early start of electrical power system development, in the context of today's needs, we talk about a series of different technological solutions whose application differs from unlimited power supplies to the daily or several days electrical energy management. These technologies could be the milestone for the further intermittent renewable energy sources integration into the electrical power system.

\section{ENERGY STORAGE TECHNOLOGIES CONNECTED TO THE TRANSMISSION GRID}

It is common to divide energy storage technologies for electrical power systems that are used today, or will be used in the future in five subcategories: mechanical, electrochemical, thermal, electrical and chemical.

It is also possible to divide energy storages into three role subcategories according to their technical characteristics: fast reacting storages whose main characteristics are fast response time and small amount of stored energy ( $\max 15$ minutes operating time) and that are able to affect power quality and power system stability; power intensive storages that have maximum operating time between 15 and 60 minutes and therefore a good power-energy ratio.
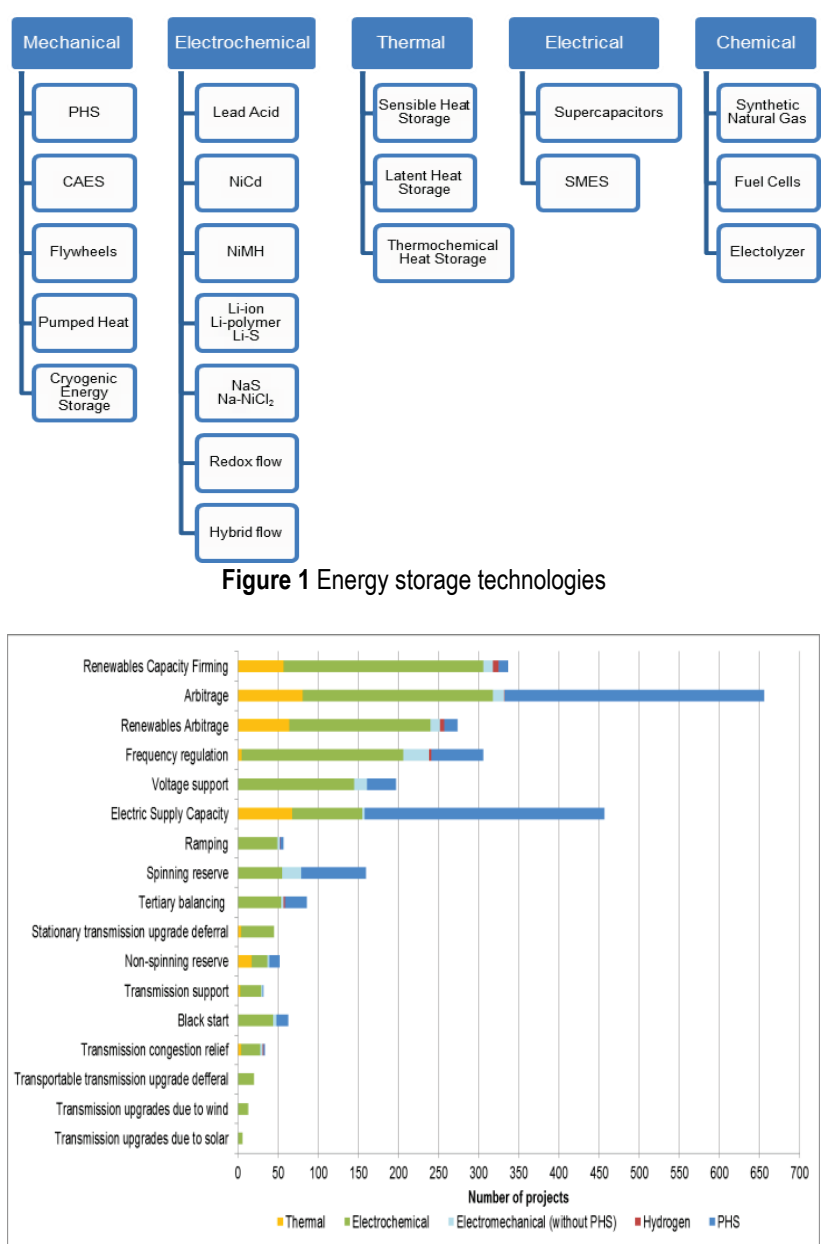

Figure 2 Energy storage projects worldwide [1]

They are used for arbitrage and can serve as back-up power systems; and energy intensive storages, that are, as their name indicates, storages of energy that operate in an hour area and are divided into: daily (c.a. 6 hours), weekly (30-40 hours), monthly (168-720 hours) and seasonal ( $\geq 720$ hours) storage. Their main role is arbitrage and are also used for transmission line investment deferral. Energy intensive storages are also useful in case of transmission congestion relief and black start. Fig. 2 shows the number of installed and planned projects considering their role in electrical power system, while their techno-economic characteristics comparison is given in Tab. 10 in Appendix. 


\subsection{Mechanical Energy Storage}

\subsubsection{Pumped Hydro Storage}

Mechanical energy storages still present the main method of storing energy mainly because of pumped hydro storage (PHS). Working principle of PHS is based on increasing the water potential energy by pumping it at a higher elevation. State-of-the-art technology is the underground PHS which eliminates geographic limitations with storing energy in underground cylinder. Energy is stored when the water is pumped into the underground tank causing the piston rising. On the other hand, electrical energy generation starts when the piston begins to descent causing water flow through the turbine and back to the top of the tank. Technical characteristics of underground PHS are very similar to the conventional one, but somewhat less efficient (75-80\%). Although the technology of conventional PHS has been present for years, researchers are trying to find solutions how to improve PHS flexibility to enable secondary regulation in pumping regime, reduce transition time between regimes and how to eliminate geographic limitations $[2,3]$.

\subsubsection{Compressed air Energy Storage}

Another mature technology commercially available is the compressed air energy storage (CAES), more accurately diabatic CAES. Compressing air technology is also possible as adiabatic CAES, isothermal CAES and underwater CAES [4]. The idea is to store (compress) air in underground tanks (usually caves, mines or caverns), as well as in underwater balloons as in the case of underwater CAES, and later use that energy to run the turbine. CAES technology researches are going in the direction of upgrading the existing system with the system for heat storing and it is expected to be realized in the coming years. Adiabatic CAES systems are in demonstration phase still commercially unavailable. As well as in the case of PHS, CAES technology is facing geographical limitations. The main goal in the future is to improve efficiency over the current value of $50 \%$. The idea for the future is to improve the turbomachinery design and maintenance, to form the salt caves, reduce the construction price of the aboveground CAES, improve thermal storages to improve efficiency and integrate CAES with other "green" technologies $[2,3,5]$.

\subsubsection{Flywheel}

Flywheel (FES) stores their energy in the form of rotational kinetic energy previously taken from an external moment. They represent well-known and very thankful technology because of their fast response time, long lifetime and high energy density. Their major drawback is a high rate of self-discharge. The majority of development, industry and installed capacities of FES are in the USA. Research of FES is going in the direction of discovering better materials for carbon and glass fibre composite flywheels to reduce the cost and improve energy density. Furthermore, engineers are trying to find electrical machines with fewer magnets, as well as magnetic and superconducting bearings for high-speed FES [3].

\subsubsection{Cryogenic Storage}

Cryogenic energy storage (LAES) uses liquid air as energy vector and is developed by two British universities (Newcastle on Tyne River and Leeds) with first project presented in 1977. The process of storing energy starts with taking the ambient heat away, which generates liquid air (cryogen) later stored in a tank under low pressure. In generation mode, cryogen is pumped on a high-pressure effecting evaporation and later on turbine where electricity is produced. Process efficiency is improved by $35 \%$ when waste heat is reused in the liquefaction process, as well as waste cold in the evaporation process. The advantage of this kind of system is higher energy density comparing to other mechanical storage technologies which leads to smaller power plant surface area. The UK still represents leading LAES developing country which in 2015 started with construction of $5 \mathrm{MW}$ hybrid LAES system with supercapacitors and flywheels. In order to continue with LAES development it is necessary to improve stability of heat/cold storage materials during charge/discharge cycles, improve cryogenic pump and compressor performances and to develop new discharge cycles $[3,6,7]$.

\subsection{Electrical Energy Storage 2.2.1 Supercapacitor}

Supercapacitor (EDLC) stores electrical potential in electrical double layer at the interface between carbon electrodes of a large surface area and liquid electrolyte. Advantages of EDLC include possibility of high power charging and discharging with a response within milliseconds and very small value of capacity loss per cycle, high efficiency $(\approx 95 \%)$ and long lifetime which makes them suitable for systems with a high number of charge/discharge cycles. Recent researches are trying to find solution how to enlarge energy density and keep positive EDLC features at the same time. Li-ion capacitor (LCAP) that uses positive electrode similar to the EDLC one and negative electrode which contains partially intercalated lithium is presented as one of the technologies that solves the problem. Projects of EDLC as independent energy storage or support to high energy density storages are in the demonstration phase. Recent researches are trying to find less toxic electrolytes for voltages over $3 \mathrm{~V}$, confirm the concept of asymmetric LCAP systems and the concept of ceramic capacitors with high permittivity dielectric and better understand charge transfer in pseudo capacities $[3,8,9]$.

\subsubsection{SMES}

SMES system stores energy in the magnetic field of superconducting coils. Using the fact that superconducting coils have a very small energy loss, SMES offers high power ratings with millisecond response time and efficiency higher than 95\%. Novelty among SMES systems are high-temperature superconductors (HTS) which allow operation at higher temperature (up to $320^{\circ} \mathrm{C}$ ) with a higher magnetic field density (up to $20 \mathrm{~T}$ ) and even higher efficiency. On the other hand, low-temperature SMES systems (LTS) with rated power up to $10 \mathrm{MW}$ and energy of $20 \mathrm{MWs}$ are already operational (for example in 
Japan). In order to commercialize SMES technology, significant price reduction is needed. That is exactly the direction in which are the multifunctional hybrid systems (LIQHYSMES) moving, combining SMES technology with liquid hydrogen technology and reducing the losses of hydrogen liquefaction and costs. Researchers are trying to improve characteristics of HTS and $\mathrm{MgB}_{2}$ magnetic tapes, find new concepts in magnet design and new cooling systems [3].

\subsection{Electrochemical Energy Storage}

Electrochemical energy storage in electrical power system is actually secondary battery, term related to rechargeable batteries. Charging and discharging process is based on reversible redox reactions. Key factors when evaluating battery lifetime are depth of discharge (DoD), charge and discharge speed and ambient temperature. Term "depth of discharge" is related to the amount of consumed energy from battery (i.e. $0 \%$ of DoD means that the battery is full). Modern battery efficiency with millisecond response is in the range from 60 to $95 \%$, depending on charge/discharge conditions. There are two battery subcategories: conventional batteries based on chemical reactions between positive electrode (cathode) and negative electrode (anode) immersed in the cell electrolyte and separated with the separator; and flow batteries which use two liquid electrolytes with different oxidation levels as energy carriers and have ion-selective membrane. Ultimate goals for the stationary battery storages until 2030 are to increase efficiency beyond $90 \%$, reduce cost to $<150$ $€ / \mathrm{kWh}$ (for MW systems) and increase lifetime to thousands of cycles. Technologies like $\mathrm{NiCd}, \mathrm{NiMH}$ and lead acid batteries are well known and in use for many years, but either because of their toxicity or unfavourable technical characteristics they are not in main focus of further transmission grid energy storage integration. Next to the Li-ion and high temperature batteries as the main technologies, more and more attention is dedicated to the research of flow and metal-air batteries since it is presumed that they could have much better technical features in the future with reasonable price [3].

\subsubsection{Li-ion Batteries}

Li-ion batteries represent the fastest growing technology of electrochemical energy storages with positive trends of rapid price reduction. Working principle is slightly different and is called intercalation principle. [10] Generally speaking, cathode of Li-ion battery is made of lithium metal oxide, anode is graphite carbon cell appropriate because of high temperature operation ability (melting point $180{ }^{\circ} \mathrm{C}$ ) and electrolyte which is either liquid based on lithium salts dissolved in organic solvent, or gel based on polymer films, typically PVDF-HFP, lithium salt and carbonate solvents [2]. Reasons for Li-ion technology attractiveness are: high energy density, high specific power, millisecond response time, low level of self-discharge and high efficiency $(85-97 \%)$. There are also some disadvantages like temperature dependent life time and DoD, complexity of BMS (Battery Management System), as well as safety aspect and environmental impact because of flammability and toxicity of some materials used in Li-ion batteries. Some of the Li-ion battery versions are: lithium-nickel manganese cobalt /lithium manganese oxide, lithium cobalt aluminium, lithium iron phosphate, lithium titanate. Recent research efforts are directed towards improving temperature characteristics, increasing the maximum power by using nanotechnologies and specific power by using new manufacturing methods for electrodes and electrolyte. Li-S batteries represent an alternative to conventional Li-ion batteries with advantages like high specific energy, low price and safety, but longer cycle life and lower level of self-discharge still remains to be attained. New materials are introduced: selenium that should replace conventional cathode and thus improve battery life time and capacity, and dimethyl sulfoxide that should replace conventional electrolyte and thus improve battery cycle life. A new generation of Li-ion batteries use solid electrolytes made of grenade type metal borohydride that improve ion exchange because of microcrystal geometry [11].

\subsubsection{NaS and $\mathrm{Na}-\mathrm{NiCl}_{2}$ Batteries}

$\mathrm{NaS}$ and $\mathrm{Na}-\mathrm{NiCl}_{2}$ batteries belong to a group of high temperature batteries. $\mathrm{NaS}$ batteries represent mature technology of energy storages in the MW range with first commercial project executed in 2002. They are based on molten sulphur and sodium that form positive and negative electrodes, while electrolyte is composed of solid beta alumina ceramics. In order to stay in a liquid state, previously mentioned materials need high temperature between 290 and $360{ }^{\circ} \mathrm{C}$. Battery itself has a low level of self-discharge at high frequency of charging-discharging change of cycles (as low as $0,05 \%$ ), due to the fact that the discharging is exothermal and charging endothermal process. However, in order to keep high temperature electric heaters are used at the inner bottom side of the battery which results with high self-discharge level of $20 \% /$ day. Another problem for all high temperature batteries is corrosion. An interesting property of this battery is its effect of pulse power delivery, which allows it to deliver more power than nominal in a certain time period (i.e. $500 \% \mathrm{P}_{\mathrm{n}}$ in 30 seconds). $\mathrm{Na}-\mathrm{NiCl}_{2}$ or Zebra battery uses nickel-chloride or mixture of nickel-chloride and ferrous-chloride instead of molten sulphur for cathode, as well as sodium chlor-aluminate electrolyte in addition to $\mathrm{NaS}$ one. Characteristics of these batteries are very similar to the $\mathrm{NaS}$ batteries (including pulse power), but the problem is that 12 to 15 hours is needed to again heat up the materials after they were in the solid state. In case of electrolyte fault it won't come to the unwanted reactions as in the case of $\mathrm{NaS}$ batteries, but rather physical barrier will appear preventing further reactions [2].

\subsection{Chemical Energy Storage}

Storing energy in chemical form is based on the transformation of electrical energy to the energy of chemical bonds. Power-to- $X(\mathrm{P} 2 \mathrm{X})$ term unites a series of generic technologies in which transformation of electrical energy from renewable energy sources to hydrogen is carried out. It also offers the option of combination with $\mathrm{CO}_{2}$ for gas synthesis (Power-to-Gas) or liquids (Powerto-Liquid) that can be used as fuels or chemicals. 
Hydrogen, which is obtained during endothermal process of water separation into hydrogen and oxygen using electricity called electrolysis, is the only serious option for chemical energy storing. Although the efficiency is relatively low, chemical storages of electrical energy possess the potential to store large amount of energy (TWh) for a longer period of time. Researchers are trying to better integrate electrolyser technology with downstream processes in the sense of cost, efficiency and ability to increase power. Except with electrolysis, it is possible to obtain hydrogen with extraction out of the fossil fuels and with production out of the refinery gas and methane [3].

\subsection{Thermal Energy Storage}

Thermal energy storages store energy in materials that have the ability to maintain temperature. There are three types of thermal storages: sensible heat storages (SHS), latent heat storages (LHS) and thermochemical heat storages (THS), with temperature ranging from $-40{ }^{\circ} \mathrm{C}$ to over $400{ }^{\circ} \mathrm{C}$. SHS is the most common way of storing thermal energy in the way in which energy is given/received while liquid or solid medium (water, sand, molten salt, stone) temperature is being changed. LHS uses the heat produced during the material aggregate state change, usually solid into liquid and vice versa, and finally THS is based on chemical reactions and sorption processes where energy is stored as a result of reversible reactions. There are some projects in the Nordic countries, the Netherlands and Germany that use underground tanks when larger amount of medium/heat has to be stored. Further development of materials used in thermal energy storages is needed in order to achieve higher energy density with a goal to reduce necessary surface area [3].

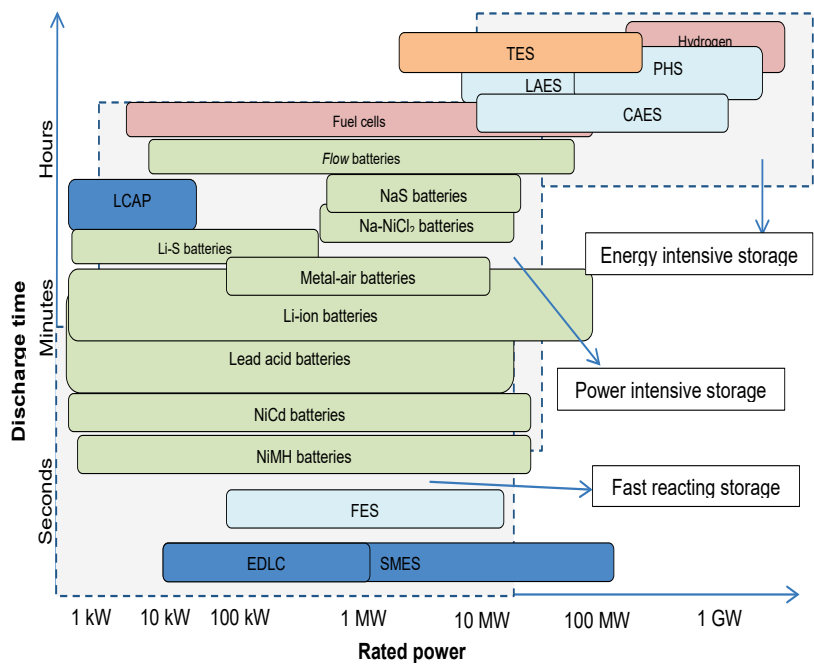

Figure 3 System power and discharge time of energy storage technologies

\section{TRANSMISSION GRID CONNECTION OF ENERGY STORAGE FACILITIES}

Energy storages behave as electric power producers or consumers on connection point, depending on their working regime. Relating to the requirements at the connection point which are different for producers and consumers of electricity, transmission grid connection of energy storage facilities represents the cross section of both types of those requirements. From TSOs point of view, the main challenge is that energy storage connection requirements are still not well defined.

This section will describe in detail requirements for customer connection based on the European Commission (EC) Regulation of 17 August 2016 concerning establishing Network Code on Demand Connection [12] as well as requirements for the connection of electricity producers based on the European Commission Regulation from 14 April 2016 concerning establishing Network Code on Requirements for Grid Connection of Generators [13]. Mandatory and exhaustive requirements are taken directly from EC Regulations and do not need further national specification, while mandatory and non-exhaustive requirements need to be additionally specified by responsible TSO depending on local power system conditions. Moreover, in the section 3.3 of this paper, main challenges regarding energy storage transmission grid integration are being discussed, all related to the fact that energy storage is an emerging technology in electrical power system and a new player inelectricity market.

\subsection{Network Rules for Consumers Connection}

According to the definition "demand facility" means an electricity-consuming facility connected to at least one connection point to a transmission or distribution system. The distribution system and/or auxiliary power supply of the production modules are not considered as demand facilities.

Demand facilities connected to the transmission grid must (among other things) comply with the following network requirements in the above network rules:

- General frequency requirements,

- General voltage requirements,

- Short-circuit requirements,

- Reactive power requirements,

- Protection requirements,

- Control requirements,

- Power quality

In addition to the above listed requirements for demand facilities that are connected to the transmission grid, other essential requirements set out in the network rules for the requirements for connecting electricity customers to the grid network (Network Code on Demand Connection) other than those specified in this work.

\subsubsection{General Frequency Requirements}

General frequency requirements describe conditions in which demand facilities must remain connected to the transmission grid during frequency change and describe frequency ranges and time periods of operation in mentioned frequency ranges with respect to the synchronous area in which they are located (Tab. 1). Time period with an asterisk means that the value should be specified by each TSO (non-exhaustive requirements). 
Table 1 Consumers frequency ranges and time periods [12]

\begin{tabular}{|c|c|c|}
\hline Synchronous area & Frequency range & Time period for operation \\
\hline \multirow{4}{*}{ Continental Europe } & $47,5-48,5 \mathrm{~Hz}$ & $>30 \min ^{*}$ \\
\hline & $48,5-49,0 \mathrm{~Hz}$ & $>\operatorname{tp}(47,5-48,5 \mathrm{~Hz})^{*}$ \\
\hline & $49,0-51,0 \mathrm{~Hz}$ & unlimited \\
\hline & $51,0-51,5 \mathrm{~Hz}$ & $30 \mathrm{~min}$ \\
\hline \multirow{4}{*}{ Nordic } & $47,5-48,5 \mathrm{~Hz}$ & $30 \mathrm{~min}$ \\
\hline & $48,5-49,0 \mathrm{~Hz}$ & $>30 \mathrm{~min}^{*}$ \\
\hline & $49,0-51,0 \mathrm{~Hz}$ & unlimited \\
\hline & $51,0-51,5 \mathrm{~Hz}$ & $30 \mathrm{~min}$ \\
\hline \multirow{6}{*}{ Great Britain } & $47,0-47,5 \mathrm{~Hz}$ & $20 \mathrm{sec}$ \\
\hline & $47,5-48,5 \mathrm{~Hz}$ & $90 \mathrm{~min}$ \\
\hline & $48,5-49,0 \mathrm{~Hz}$ & $>90 \min ^{*}$ \\
\hline & $49,0-51,0 \mathrm{~Hz}$ & unlimited \\
\hline & $51,0-51,5 \mathrm{~Hz}$ & $90 \mathrm{~min}$ \\
\hline & $51,5-52,0 \mathrm{~Hz}$ & $15 \mathrm{~min}$ \\
\hline \multirow{4}{*}{$\begin{array}{c}\text { Ireland and Northern } \\
\text { Ireland }\end{array}$} & $47,5-48,5 \mathrm{~Hz}$ & $90 \mathrm{~min}$ \\
\hline & $48,5-49,0 \mathrm{~Hz}$ & $>90 \min ^{*}$ \\
\hline & $49,0-51,0 \mathrm{~Hz}$ & unlimited \\
\hline & $51,0-51,5 \mathrm{~Hz}$ & $90 \mathrm{~min}$ \\
\hline \multirow{4}{*}{ Baltic } & $47,5-48,5 \mathrm{~Hz}$ & $>30 \min ^{*}$ \\
\hline & $48,5-49,0 \mathrm{~Hz}$ & $>\operatorname{tp}(47,5-48,5 \mathrm{~Hz})^{*}$ \\
\hline & $49,0-51,0 \mathrm{~Hz}$ & unlimited \\
\hline & $51,0-51,5 \mathrm{~Hz}$ & $>30 \min ^{*}$ \\
\hline
\end{tabular}

Table 2 Consumers voltage ranges and time periods for voltages up to $300 \mathrm{kV}$ [12]

\begin{tabular}{|c|c|c|}
\hline Synchronous area & Voltage range & Time period for operation \\
\hline \multirow{2}{*}{ Continental Europe } & $0,90-1,118$ p.u. & unlimited \\
\cline { 2 - 4 } & $1,118-1,15$ p.u. & $\langle 20,60\rangle$ min* \\
\hline Nordic & $0,90-1,05$ p.u. & unlimited \\
\cline { 2 - 4 } & $1,05-1,10$ p.u. & 60 min \\
\hline Great Britain & $0,90-1,10$ p.u. & unlimited \\
\hline $\begin{array}{c}\text { Ireland and Northern } \\
\text { Ireland }\end{array}$ & $0,90-1,18$ p.u. & unlimited \\
\hline \multirow{2}{*}{ Baltic } & $0,90-1,118$ p.u. & unlimited \\
\cline { 2 - 4 } & $1,118-1,15$ p.u. & 20 min \\
\hline
\end{tabular}

Table 3 Consumers voltage ranges and time periods for voltages above $300 \mathrm{kV}$ $[12]$

\begin{tabular}{|c|c|c|}
\hline Synchronous area & Voltage range & Time period for operation \\
\hline \multirow{2}{*}{ Continental Europe } & 0,90 - 1,05 p.u. & unlimited \\
\hline & $1,05-1,10$ p.u. & $\langle 20,60\rangle$ min* \\
\hline \multirow{2}{*}{ Nordic } & $0,90-1,05$ p.u. & unlimited \\
\hline & $1,05-1,10$ p.u. & $<60$ min* \\
\hline \multirow{2}{*}{ Great Britain } & 0,90 - 1,05 p.u. & unlimited \\
\hline & 1,05 - 1,10 p.u. & $15 \mathrm{~min}$ \\
\hline $\begin{array}{l}\text { Ireland and Northern } \\
\text { Ireland }\end{array}$ & 0,90 - 1,05 p.u. & unlimited \\
\hline \multirow{2}{*}{ Baltic } & $0,90-1,097$ p.u. & unlimited \\
\hline & 1,097 - 1,15 p.u. & $20 \mathrm{~min}$ \\
\hline
\end{tabular}

\subsubsection{General Voltage Requirements}

The general voltage requirements describe conditions in which demand facilities must remain connected to the transmission grid when voltage changes and periods of operation in mentioned voltage ranges in relation to the synchronous area in which they are located. The general voltage requirements for voltages from $110 \mathrm{kV}$ up to 300 $\mathrm{kV}$ excluded are listed in Tab. 2, while for those from 300 $\mathrm{kV}$ included up to $400 \mathrm{kV}$ are listed in Tab. 3. Time period with an asterisk means that the value should be specified by each TSO (non-exhaustive requirements).

\subsubsection{Short-Circuit Requirements}

Short-circuit requirements refer to the maximum value of short circuit current at the connection site that demand facility connected to the transmission system must be able to withstand. The relevant TSO submits to the demand facility owner connected to the transmission system the minimum and maximum short circuit current that can be expected at the connection site.

\subsubsection{Reactive Power Requirements}

Reactive power requirements refer to demand facilities and distribution connected to the transmission grid. As this emphasis is placed on demand facilities, further descriptions will only refer to demand facilities.

The demand facilities connected to the transmission system must be able to maintain steady-state operation at the connection point in the reactive power range specified by the relevant TSO in accordance with the conditions that the consumption and delivery of reactive power will not exceed 48 percent of the highest capacity for consumption or delivery (whichever is greater) unless the demand facility connected to the transmission grid proves technical or financial benefit for the system, and the authorized TSO accepts it.

\subsubsection{Control Requirements}

Control requirements related to plans and procedures of the various customer devices connected to the transmission network that are jointly agreed between the customer and TSO, and are important for the system security. Control requirements relate to: isolated operation, damping of oscillation, transmission grid disturbances and automatic circuit-breaker re-closure.

\subsubsection{Power Quality}

Power quality requirements refer to customer devices connected to the transmission grid requiring that their operation does not cause distortion (voltage and current) or voltage fluctuations. The maximum values of voltage and current distortions at the point of sale of customers are governed by the standards and network rules of individual TSOs.

\subsection{Network Codes on Requirements for Producers Connection}

Unlike electricity consumers, electricity producers directly contribute to the safety of the power system depending on their characteristics and technical abilities of their production modules. This paper briefly describes the most basic requirements to be met by power plants.

According to the definition of the EC, power plants are the facilities that convert primary energy into electricity and which consist of at least one production module connected to the grid at one connection point. The production module is a synchronous module to produce electricity or the module of the power park.

As demand facilities have to meet earlier requirements, same producers must among other, meet 
certain requirements in order to be able to connect to the transmission power grid. Electricity producers connected to the transmission grid (level at or above $110 \mathrm{kV}$, type D according to the network requirements for the connection of electricity producers to the grid) must meet, among other required in network rules (Network Code on Requirements for Grid Connection of Generators), the following requirements:

- General frequency requirements,

- General voltage stability requirements,

- Ability to pass through failure requirements

\subsubsection{General Frequency Requirements for Production Modules Connected at a Voltage Level at or Above 110 kV}

The general frequency requirements for production modules connected at the voltage level at or above $110 \mathrm{kV}$ (type D according to the network requirements for the connection of power producers to the grid) describe the frequency ranges and (shortest) periods of operation in the specified frequency ranges in relation to the synchronous area in which the production module must be capable of working, so as not to disconnect it from the grid. The general frequency requirements are listed in Tab. 4. Time period with an asterisk means that the value should be specified by each TSO (non-exhaustive requirements).

Table 4 Producers frequency ranges and time periods [13]

\begin{tabular}{|c|c|c|}
\hline Synchronous area & Frequency range & Time period for operation \\
\hline \multirow{4}{*}{ Continental Europe } & $47,5 \mathrm{~Hz}-48,5 \mathrm{~Hz}$ & $>30$ min* \\
\hline & $48,5 \mathrm{~Hz}-49,0 \mathrm{~Hz}$ & $>\operatorname{tp}(47,5-48,5 \mathrm{~Hz})^{*}$ \\
\hline & $49,0 \mathrm{~Hz}-51,0 \mathrm{~Hz}$ & unlimited \\
\hline & $51,0 \mathrm{~Hz}-51,5 \mathrm{~Hz}$ & $30 \mathrm{~min}$ \\
\hline \multirow{4}{*}{ Nordic } & $47,5 \mathrm{~Hz}-48,5 \mathrm{~Hz}$ & $30 \mathrm{~min}$ \\
\hline & $48,5 \mathrm{~Hz}-49,0 \mathrm{~Hz}$ & $>30 \mathrm{~min}^{*}$ \\
\hline & $49,0 \mathrm{~Hz}-51,0 \mathrm{~Hz}$ & unlimited \\
\hline & $51,0 \mathrm{~Hz}-51,5 \mathrm{~Hz}$ & $30 \mathrm{~min}$ \\
\hline \multirow{6}{*}{ Great Britain } & $47,0 \mathrm{~Hz}-47,5 \mathrm{~Hz}$ & $20 \mathrm{sec}$ \\
\hline & $47,5 \mathrm{~Hz}-48,5 \mathrm{~Hz}$ & $90 \mathrm{~min}$ \\
\hline & $48,5 \mathrm{~Hz}-49,0 \mathrm{~Hz}$ & $>90$ min* \\
\hline & $49,0 \mathrm{~Hz}-51,0 \mathrm{~Hz}$ & unlimited \\
\hline & $51,0 \mathrm{~Hz}-51,5 \mathrm{~Hz}$ & $90 \mathrm{~min}$ \\
\hline & $51,5 \mathrm{~Hz}-52,0 \mathrm{~Hz}$ & $15 \mathrm{~min}$ \\
\hline \multirow{4}{*}{$\begin{array}{l}\text { Ireland and Northern } \\
\text { Ireland }\end{array}$} & $47,5 \mathrm{~Hz}-48,5 \mathrm{~Hz}$ & $90 \mathrm{~min}$ \\
\hline & $48,5 \mathrm{~Hz}-49,0 \mathrm{~Hz}$ & $>90$ min* \\
\hline & $49,0 \mathrm{~Hz}-51,0 \mathrm{~Hz}$ & unlimited \\
\hline & $51,0 \mathrm{~Hz}-51,5 \mathrm{~Hz}$ & $90 \mathrm{~min}$ \\
\hline \multirow{4}{*}{ Baltic } & $47,5 \mathrm{~Hz}-48,5 \mathrm{~Hz}$ & $>30$ min* \\
\hline & $48,5 \mathrm{~Hz}-49,0 \mathrm{~Hz}$ & $>\operatorname{tp}(47,5-48,5 \mathrm{~Hz})^{*}$ \\
\hline & $49,0 \mathrm{~Hz}-51,0 \mathrm{~Hz}$ & unlimited \\
\hline & $51,0 \mathrm{~Hz}-51,5 \mathrm{~Hz}$ & $>30 \mathrm{~min} *$ \\
\hline
\end{tabular}

\subsubsection{General Requirements for Voltage Stability for Manufacturing Modules Connected at a Voltage Level at or Above $110 \mathrm{kV}$}

General voltage stability requirements for power generating modules connected at the voltage level at or above $110 \mathrm{kV}$ describe (type $\mathrm{D}$ according to the network code on requirements for grid connection of generators) conditions in which power plant facilities must remain connected to the transmission grid during voltage change and during working period in specified voltage ranges in relation to the synchronous area.

The general voltage requirements describe the shortest periods as the power generating module must be capable of working for voltages deviating from the reference values of 1 p.u. at the connection site without causing its disconnection from the network for voltages from $300 \mathrm{kV}$ included to $400 \mathrm{kV}$ in Tab. 5, while the shortest periods as the power generating module must be capable of working for voltages deviating from the reference values of 1 p.u. at the connection site without causing its disconnection from the network for voltages from $100 \mathrm{kV}$ to $300 \mathrm{kV}$ excluded described in the Tab. 6 of this section. Time period with an asterisk means that the value should be specified by each TSO (non-exhaustive requirements).

\begin{tabular}{|c|c|c|}
\hline Synchronous area & Voltage range & Time period for operation \\
\hline \multirow{3}{*}{ Continental Europe } & 0,85 - 0,90 p.u. & $60 \mathrm{~min}$ \\
\hline & 0,90 - 1,05p.u. & unlimited \\
\hline & 1,05 - 1,10p.u. & $\langle 20,60\rangle \min *$ \\
\hline \multirow{2}{*}{ Nordic } & 0,90 - 1,05p.u. & unlimited \\
\hline & 1,05 - 1,10p.u. & $<60$ min* \\
\hline \multirow{2}{*}{ Great Britain } & 0,90 - 1,05p.u. & unlimited \\
\hline & 1,05 - 1,10p.u. & $15 \mathrm{~min}$ \\
\hline $\begin{array}{c}\text { Ireland and Northern } \\
\text { Ireland }\end{array}$ & 0,90 - 1,05p.u. & unlimited \\
\hline \multirow{3}{*}{ Baltic } & 0,88 - 0,90p.u. & $20 \mathrm{~min}$ \\
\hline & $0,90-1,097$ p.u. & unlimited \\
\hline & 1,097 - 1,15p.u. & $20 \mathrm{~min}$ \\
\hline
\end{tabular}

Table 6 Producers voltage ranges and time periods for voltages up to $300 \mathrm{kV}$ [13]

\begin{tabular}{|c|c|c|}
\hline Synchronous area & Voltage range & Time period for operation \\
\hline \multirow{3}{*}{ Continental Europe } & $0,85-0,90$ p.u. & 60 min \\
\cline { 2 - 4 } & $0,90-1,118$ p.u. & unlimited \\
\cline { 2 - 4 } & $1,118-1,15$ p.u. & $\langle 20,60\rangle$ min* \\
\hline \multirow{2}{*}{ Nordic } & $0,90-1,05$ p.u. & unlimited \\
\cline { 2 - 4 } & $1,05-1,10$ p.u. & 60 min \\
\hline Great Britain & $0,90-1,10$ p.u. & unlimited \\
\hline $\begin{array}{c}\text { Ireland and Northern } \\
\text { Ireland }\end{array}$ & $0,90-1,118$ p.u. & unlimited \\
\hline \multirow{2}{*}{ Baltic } & $0,85-0,90$ p.u. & 30 min \\
\cline { 2 - 3 } & $0,90-1,118$ p.u. & unlimited \\
\cline { 2 - 3 } & $1,118-1,15$ p.u. & 20 min \\
\hline
\end{tabular}

\subsubsection{Requirements for the Ability to Pass Through Failure for Production Modules Connected at a Voltage Level at or Above $110 \mathrm{kV}$}

Requirements for the ability to pass through the failure of a production module connected at a voltage level at or above $110 \mathrm{kV}$ describe (type $\mathrm{D}$ according to the network rules for the requirements for connecting electricity producers to the grid) describe the time and voltage parameters that must meet the synchronous manufacturing modules to "stay" on the network when a network failure occurs.

Fig. 4 clearly illustrates the diagram of the production module passing through a fault condition in the network. Fig. 4 also shows the lower limit of the voltage time characteristics at the site where the production unit is connected. The lower border is expressed in the ratio of the actual voltage value at the connection point and the reference value of 1 p.u. before and after the fault in the 
network. The voltage and time parameters shown in Fig. 4 for the ability to pass through synchronous generator failure state are shown in Tab. 7.

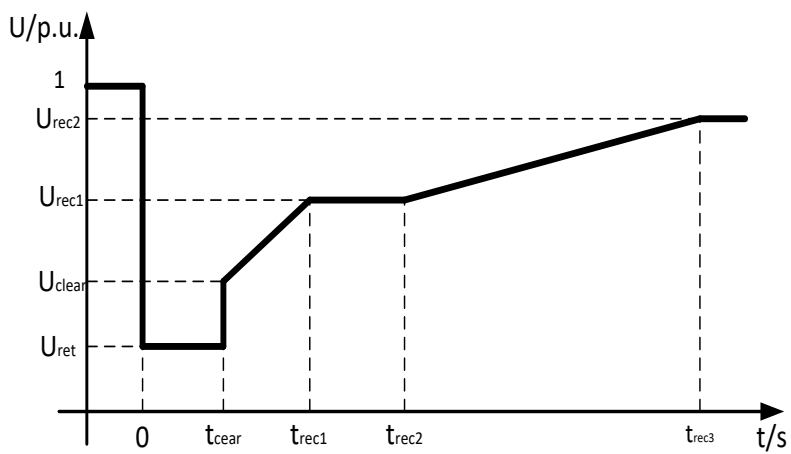

Figure 4 Fault-ride-through profile of power-generation module [13]

Table 7 Parameters for Fig. 4 for fault-ride-through capability of synchronous power-generating modules [13]

\begin{tabular}{|c|c|c|c|}
\hline \multicolumn{2}{|c|}{$\begin{array}{c}\text { Voltage } \\
\text { parameters (p.u.) }\end{array}$} & \multicolumn{2}{|r|}{ Time parameters (seconds) } \\
\hline$U_{\text {ret }}$ & 0 & $t_{\text {clear }}$ & $\begin{array}{c}0,14-0,15 \text { (or } 0,14-0,25 \text { if system } \\
\text { protection and secure operation so } \\
\text { require) }\end{array}$ \\
\hline$U_{\text {clear }}$ & 0,25 & $t_{\mathrm{rec} 1}$ & $t_{\text {clear }}-0,45$ \\
\hline$U_{\text {rec1 }}$ & $0,5-0,7$ & $t_{\mathrm{rec} 2}$ & $t_{\mathrm{rec} 1}-0,7$ \\
\hline$U_{\text {rec2 }}$ & $0,85-0,9$ & $t_{\mathrm{rec} 3}$ & $t_{\mathrm{rec} 2}-1,5$ \\
\hline
\end{tabular}

\subsection{Challenges Regarding Energy Storage Transmission Grid Integration}

Challenges regarding energy storage transmission grid integration refer to the technical and regulatory challenges. On the one hand, the development of energy storage technologies requires additional innovation and breakthrough in capacity, long-lifespan, high-security for electrochemical storage and low-cost. Simultaneously, it is necessary to focus on energy storage simulation modelling and operational optimization from theoretical point of view [14]. On the other hand, regulatory challenges relate to each country separately, but according to Eurobat [15] there are five key barriers preventing energy storage deployment in Europe: a) lack of definition of energy storage and double grid fees; b) unclear ownership rights; c) value streams of ancillary services; d) curtailment and balancing responsibilities; e) electricity pricing. The EC gave guidelines in the Electricity Directive facing stated problems in order to encourage European countries to include rapidly growing energy storage technology into their national grid codes. First problem refers to the fact that energy storage is not recognized as a "new asset" in the electricity grid. In the Electricity Directive from February 2017 [16] a new definition of energy storage is proposed stating: "energy storage" means, in the electricity system, deferring an amount of electricity that was generated to the moment of use, either as final energy or converted into another energy carrier. The second problem is that energy storage connected to the transmission system in some countries pays both generation and demand system charges on discharging and charging respectively. Since it is considered as a big disadvantage in comparison with generation providing similar services, it is proposed that only one charge should be paid. Two options were proposed in the UK: a) define storage as import/export Balancing Mechanism Unit (BMU) irrespective of their actions in any particular settlement period and net off opposite flows; b) charge balancing services use of system based on gross import or gross export. It was also suggested to remove transmission residual demand charges for standalone storage or storage co-located with generation assets [17]. Another problem is related to ownership of storage and provision of ancillary services by TSOs. On the one hand, in the Electricity Directive it is stated that TSO shall not own, manage or operate energy storage facilities and shall not own directly or indirectly control assets that provide ancillary services. On the other hand, TSOs can own, manage or operate storage facilities or assets providing non-frequency ancillary services if: a) there is no interest from other parties; b) facilities are necessary for the efficient, reliable and secure operation of the system and they are not used to sell electricity to the market; c) the regulatory authority has assessed the necessity of such derogation taking into account the conditions under points a) and b). However, they have the obligation to perform at regular intervals or at least every five years a public consultation for the required storage services in order to assess the potential interest of market parties to invest in such facilities and terminate its own storage activities in case third parties can provide the service in a cost-effective manner. In that way, storages that are able to provide system services are rewarded. Detailed clarification of derogation clauses is still needed. In order to eliminate possibility/incentives to curtail, the EC in the Electricity Regulation document [18] states that the provision of market-based resources will be open to all generation technologies, including storage. Furthermore, all market participants shall be responsible for imbalances they cause in the system and electricity prices shall reflect actual demand and supply. There are a few examples of countries that have successfully adapted their energy markets to effectively allow energy storage to prosper, i.e. Italy allows the TSO to develop and manage distributed storage facilities and storage systems in order to increase the dispatch of intermittent generation.

\section{WORLDWIDE EXAMPLES OF TRANSMISSION GRID CONNECTION OF ENERGY STORAGE}

In this section overview of the worldwide examples of transmission grid connection of energy storage is given. The overview includes hitherto operational projects, as well as projects which still need to be connected to the grid (contracted, announced and under construction projects).

As mentioned earlier, dominant technology regarding the connected power is the technology of PHS with 184 $\mathrm{GW}$, followed by thermal energy storages with 3,21 GW, electrochemical storages with 1,64 GW and finally group of electrical and mechanical storages other than PHS with 1,37 GW. Leading technology regarding number of future projects as well as a future power to be installed on the electrical power grid is the electrochemical energy storage technology with a power of 1,07 GW. Leading countries regarding hitherto operational projects are China, Japan and USA, while USA leads with planned projects and planned power with 7,5 $\mathrm{GW}$ and 164 projects. Looking from European perspective Germany, Italy and Spain are 
the countries with the most of the operational projects, and that trend will probably continue in the future. Considering transmission grid, the most interesting storages are energy intensive and power intensive storages, according to Fig. 3. Projects that refer to fast reacting energy storages are mainly in a lower stage of development when connection to the transmission grid is taken into account and the practice is to combine them with storages possessing a higher amount of energy into hybrid projects. A few larger projects without PHS that are, or will be connected to the transmission grid in the future are given bellow [1].

Table 8 Planned energy storage projects

\begin{tabular}{|c|c|c|c|c|}
\hline Type & Name & Power & Energy & Country \\
\hline CAES & Adele & $260 \mathrm{MW}$ & $1000 \mathrm{MWh}$ & GER \\
\hline CAES & Larne & $330 \mathrm{MW}$ & $2000 \mathrm{MWh}$ & UK \\
\hline CAES & Apex & $\begin{array}{c}317 \mathrm{MW} \\
(476 \mathrm{MW})\end{array}$ & $30000 \mathrm{MWh}$ & USA \\
\hline CAES & PG\&E & $300 \mathrm{MW}$ & $3000 \mathrm{MWh}$ & USA \\
\hline FES & Energy Nuevo & $20 \mathrm{MW}$ & $80 \mathrm{MWh}$ & USA \\
\hline Li ion & AES Alamitos & $3 \times 100 \mathrm{MW}$ & $3 \times 400 \mathrm{MWh}$ & USA \\
\hline Li ion & AES Kilroot & $100 \mathrm{MW}$ & & UK \\
\hline VRB & $\begin{array}{c}\text { Dalian } \\
\text { RONGKE }\end{array}$ & $200 \mathrm{MW}$ & $800 \mathrm{MWh}$ & China \\
\hline Li ion & $\begin{array}{c}\text { EDF West } \\
\text { Burton }\end{array}$ & $49 \mathrm{MW}$ & & UK \\
\hline Li ion & $\begin{array}{c}\text { Centrica } \\
\text { Roosecote }\end{array}$ & $49 \mathrm{MW}$ & $24,5 \mathrm{MWh}$ & UK \\
\hline
\end{tabular}

Table 9 Installed energy storage projects

\begin{tabular}{|c|c|c|c|c|}
\hline Type & Name & Power & Energy & Country \\
\hline CAES & Huntorf & $321 \mathrm{MW}$ & $640 \mathrm{MWh}$ & GER \\
\hline CAES & McIntosh & $110 \mathrm{MW}$ & $2860 \mathrm{MWh}$ & USA \\
\hline Thermal & Crescent Dunes & $110 \mathrm{MW}$ & $1100 \mathrm{MWh}$ & USA \\
\hline FES & Stephentown, NY & $20 \mathrm{MW}$ & $5 \mathrm{MWh}$ & USA \\
\hline FES & $\begin{array}{c}\text { Hazle Spindle, } \\
\text { LLC }\end{array}$ & $20 \mathrm{MW}$ & $5 \mathrm{MWh}$ & USA \\
\hline Li ion & $\begin{array}{c}\text { Hornsdale Power } \\
\text { Reserve }\end{array}$ & $100 \mathrm{MW}$ & $129 \mathrm{MWh}$ & AUS \\
\hline $\mathrm{Li}$ ion & AES SDG\&E & $30 \mathrm{MW}$ & $120 \mathrm{MWh}$ & USA \\
\hline $\mathrm{NaS}$ & $\begin{array}{c}\text { Terna SANC } \\
(2 \times 12+10,8 \\
\mathrm{MW}\end{array}$ & $\begin{array}{c}232 \mathrm{MWh} \\
(2 \times 80+72 \\
\mathrm{MWh})\end{array}$ & Italy \\
\hline $\mathrm{NaS}$ & Rokkasho Village & $34 \mathrm{MW}$ & $245 \mathrm{MWh}$ & JAP \\
\hline $\mathrm{NaS}$ & $\begin{array}{c}\text { Kyushu Electric } \\
\text { Buzen }\end{array}$ & $50 \mathrm{MW}$ & $300 \mathrm{MWh}$ & JAP \\
\hline
\end{tabular}

\section{CONCLUSION}

In this paper overview of energy storage technologies is given and their techno-economic characteristics are compared, as well as different transmission grid connection requirements regarding production and consumption grid assets. Moreover, some of the major challenges that need to be considered in order to increase energy storage integration into the transmission grid are discussed. Finally, significant worldwide installed and planned energy storage projects are presented.

\section{Acknowledgements}

This work has been supported in part by Croatian Science Foundation and Croatian Transmission System Operator (HOPS) under the project Smart Integration of RENewables (I-2583-2015).

\section{REFERENCES}

[1] See http://www.energystorageexchange.org/

[2] Gallo, A., Simões-Moreira, J., Costa, H., Santos, M., \& Santos, E. M. (2016). Energy storage in the energy transition context: A technology review. Renewable and Sustainable Energy Reviews, 65, 800-822. https://doi.org/10.1016/j.rser.2016.07.028

[3] EASE-EERA-Storage-Technology-Development-Roadmap -2017-HR. (2017). Retrieved from https://eera-es.eu/ technical-documents/

[4] See https://hydrostor.ca/

[5] Helsingen, E. M. (2015, June 24). Adiabatic compressed air energy storage. Retrieved from http://hdl.handle.net/ $11250 / 2350057 /$

[6] Ding, Y., Li, Y., Li, D., Radcliffe, J., \& Huang, Y. (2015). Cryogenic Energy Storage. Handbook of Clean Energy Systems, 1-15. https://doi.org/10.1002/9781118991978.hces200

[7] Seehttps://www.highviewpower.com/technology/

[8] Sun, F., Gao, J., Zhu, Y., Pi, X., Wang, L., Liu, X., \& Qin, Y. (2017). A high performance lithium ion capacitor achieved by the integration of a Sn-C anode and a biomassderived microporous activated carbon cathode. Scientific Reports, 7(1). https://doi.org/10.1038/srep40990

[9] Electrical Energy Storage. (2015). Retrieved from http://www.iec.ch/whitepaper/energystorage/

[10] Urban, A., Seo, D., \& Ceder, G. (2016). Computational understanding of Li-ion batteries. npj Computational Materials, 2(1). https://doi.org/10.1038/npjcompumats.2016.2

[11] Amirante, R., Cassone, E., Distaso, E., \& Tamburrano, P. (2017). Overview on recent developments in energy storage: Mechanical, electrochemical and hydrogen technologies. Energy Conversion and Management, 132, 372-387. https://doi.org/10.1016/j.enconman.2016.11.046

[12] Commission Regulation (EU) 2016/1388 of 17 August 2016 on Establishing a network code on Demand Connection. (2016). Official Journal of the European Union, L223/10, $10-54$.

[13] Commission Regulation (EU) 2016/631 of 14 April 2016 on Establishing a Network Code on Requirements for Grid Connection of Generators. (2016). Official Journal of the European Union, L112/1, 1-68.

[14] Yao, L., Yang, B., Cui, H., Zhuang, J., Ye, J., \& Xue, J. (2016). Challenges and progresses of energy storage technology and its application in power systems. Journal of Modern Power Systems and Clean Energy, 4(4), 519-528. https://doi.org/10.1007/s40565-016-0248-x

[15] Westgeest, A. (2017). EU regulatory barriers to energy storage - how to unlock the grid code? Retrieved from https://eera-es.eu/events-jp-es-workshops/

[16] Proposal for a Directive of the European Parliament and of the Council on Common Rules for the Internal Market in Electricity. (2017). Retrieved from https://eur-lex.europa. $\mathrm{eu} /$ legal-content/EN/TXT/?uri=CELEX: 52016PC0864R $(01)$

[17] Targeted Charging Review: A consultation. (2018, February 23). Retrieved from https://www.ofgem.gov.uk/publications -and-updates/targeted-charging-review-consultation/

[18] Proposal for a Regulation of the European Parliament and of the Council on the Internal Market for Electricity. (2016). Retrieved from https://eur-lex.europa.eu/legal-content/EN/ TXT/?uri=COM:2016:861:FIN

[19] See http://ease-storage.eu/energy-storage/technologies/.

[20] World Energy Resources E-storage: Shifting from cost to value. (2016). Retrieved from https://www.worldenergy.org/ publications/2016/e-storage-shifting-from-cost-to-value2016/

[21] Akinyele, D., \& Rayudu, R. (2014). Review of energy storage technologies for sustainable power networks. 
Sustainable Energy Technologies and Assessments, 8, 74-91. https://doi.org/10.1016/j.seta.2014.07.004

[22] Chang, H., Canfield, N. L., Jung, K., Sprenkle, V. L., \& Li, G. (2017). Advanced Na-NiCl2 Battery Using NickelCoated Graphite with Core-Shell Microarchitecture. ACS Applied Materials \& Interfaces, 9(13), 11609-11614. https://doi.org/10.1021/acsami.7b00271

[23] Electricity storage and renewables: Costs and markets to 2030. (2017). Retrieved from http://irena.org/publications/ 2017/Oct/Electricity-storage-and-renewables-costs-andmarkets/

[24] Boicea, V. A. (2014). Energy Storage Technologies: The Past and the Present. Proceedings of the IEEE, 102(11), 1777-1794. https://doi.org/10.1109/jproc.2014.2359545

[25] Taylor, P., Bolton, R., Stone, D., Zhang, X-P., Martin, C., \& Upham, P. (2012). Pathways for Energy Storage in the UK: A Report for the Centre for Low Carbon Futures. Retrieved from https://www.research.ed.ac.uk/portal/en/publications/ pathways-for-energy-storage-in-the-uk $(5282 \mathrm{c} 5 \mathrm{fb}$-a2ee4ef4-9da8-d3ecc060d5cf).html

[26] Luo, X., Wang, J., Dooner, M., \& Clarke, J. (2015). Overview of current development in electrical energy storage technologies and the application potential in power system operation. Applied Energy, 137, 511-536. https://doi.org/10.1016/j.apenergy.2014.09.081

[27] Zhang, H., Baeyens, J., Cáceres, G., Degrève, J., \& Lv, Y. (2016). Thermal energy storage: Recent developments and practical aspects. Progress in Energy and Combustion Science, 53, 1-40. https://doi.org/10.1016/j.pecs.2015.10.003

[28] Li, Y., \& Lu, J. (2017). Metal-Air Batteries: Will They Be the Future Electrochemical Energy Storage Device of Choice? ACS Energy Letters, 2(6), 1370-1377. https://doi.org/10.1021/acsenergylett.7b00119

[29] See https://energy.gov/eere/fuelcells/doe-technical-targetsfuel-cell-systems-stationary-combined-heat-and-power/

[30] Venis, M. (n.d.). Standard vs Trickle Charging NiCd and NiMH Batteries. Retrieved from http://www.vencon.com/ charging-nicd-nimh-batteries/

[31] See http://energystorage.org/energy-storage/energy-storagetechnologies/

[32] Barbour, E. (n.d.). Energy Storage Technologies Explained. Retrieved from http://energystoragesense.com/energystorage-technologies/

\section{Contact information:}

Zlatko OFAK, MSc

Croatian Transmission System Operator Ltd.

Kupska 4, 10000 Zagreb

zlatko.ofak@hops.hr

Alan ŽUPAN, PhD

Croatian Transmission System Operator Ltd.

Kupska 4, 10000 Zagreb

alan.zupan@hops.hr

Tomislav PLAVŠIĆ, PhD

Croatian Transmission System Operator Ltd.

Kupska 4, 10000 Zagreb

tomislav.plavsic@hops.hr 


\section{$7 \quad$ Appendix}

Table 10 Energy storage technologies comparison [2, 6, 9, 11, 19-32]

\begin{tabular}{|c|c|c|c|c|c|c|c|c|c|}
\hline Storage type & $\begin{array}{c}\text { Specific } \\
\text { energy } \\
(\mathrm{Wh} / \mathrm{kg})\end{array}$ & $\begin{array}{l}\text { Specific power } \\
(\mathrm{W} / \mathrm{kg})\end{array}$ & Price & Cycles & Eff. & $\begin{array}{l}\text { Life time } \\
\quad(y r .)\end{array}$ & Maturity & $\begin{array}{l}\text { Self-disch. } \\
\text { /day }\end{array}$ & $\begin{array}{l}\text { Respons } \\
\text { e time }\end{array}$ \\
\hline PHS & $0,5-1,5$ & - & $\begin{array}{c}500-2000 € / \mathrm{kW} \\
8-70 € / \mathrm{kWh}\end{array}$ & $20000-50000$ & $65-87 \%$ & $40-60$ & mature & $0,01 \%$ & $\leq 3 \min$ \\
\hline CAES & $30-60$ & - & $\begin{array}{l}300-1300 € / \mathrm{kW} \\
40-140 € / \mathrm{kWh}\end{array}$ & $10000-50000$ & $40-70 \%$ & $20-50$ & mature & $0-0,5 \%$ & $\leq 10 \mathrm{~min}$ \\
\hline FES & $5-200$ & $400-1500$ & $\begin{array}{l}1000-2000 € / \mathrm{kW} \\
500-5000 € / \mathrm{kWh}\end{array}$ & $>100000$ & $75-95 \%$ & $15-20$ & $\begin{array}{l}\text { mature for } \\
\text { low speed }\end{array}$ & $60 \%$ & $\mathrm{~ms}-\mathrm{s}$ \\
\hline LAES & 214 & - & $\begin{array}{c}500-3500 € / \mathrm{kW} \\
60-600 € / \mathrm{kWh}\end{array}$ & $22000-30000$ & $50-100 \%$ & $30-40$ & $\mathrm{R} \& \mathrm{D}$, demo & $0-0,5 \%$ & $5-10 \mathrm{~min}$ \\
\hline EDLC & $4-15$ & $10000-20000$ & $\begin{array}{c}100-500 € / \mathrm{kW} \\
10000-20000 € / \mathrm{kWh}\end{array}$ & $500 \mathrm{k}-1 \mathrm{M}$ & $85-95 \%$ & $10-30$ & commercial & $20-40 \%$ & $\mathrm{~ms}$ \\
\hline SMES & $1-75$ & $10-100 \mathrm{k}$ & $\begin{array}{c}170-340 € / \mathrm{kW} \\
850-8500 € / \mathrm{kWh}\end{array}$ & $\inf$ & $80-95 \%$ & 30 & commercial & $10-15 \%$ & $\mathrm{~ms}$ \\
\hline $\begin{array}{c}\text { Lead acid } \\
\text { battery }\end{array}$ & $25-50$ & $75-300$ & $\begin{array}{c}100-500 € / \mathrm{kW} \\
100-830 € / \mathrm{kWh}\end{array}$ & $500-3200$ & $70-90 \%$ & $5-15$ & $\begin{array}{c}\text { mature, } \\
\text { commercial }\end{array}$ & $0,1-0,3 \%$ & $\mathrm{~ms}$ \\
\hline NiCd battery & $30-80$ & $150-300$ & $\begin{array}{c}500-1500 € / \mathrm{kW} \\
400-1800 € / \mathrm{kWh}\end{array}$ & $1000-5000$ & $60-73 \%$ & $10-20$ & mature & $1 \%$ & $\mathrm{~ms}$ \\
\hline $\begin{array}{l}\text { NiMH } \\
\text { battery }\end{array}$ & $60-120$ & $250-1000$ & $\begin{array}{c}400-1500 € / \mathrm{kW} \\
750-3000 € / \mathrm{kWh}\end{array}$ & $1000-5000$ & $60-75 \%$ & $10-15$ & mature & $1 \%$ & $\mathrm{~ms}$ \\
\hline $\begin{array}{l}\text { Li-ion } \\
\text { battery }\end{array}$ & $100-270$ & $150-2000$ & $\begin{array}{c}150-3300 € / \mathrm{kW} \\
700-3200 € / \mathrm{kWh}\end{array}$ & $2000-20000$ & $85-98 \%$ & $15-20$ & $\begin{array}{c}\text { commercial, } \\
\text { demo }\end{array}$ & $0,1-0,3 \%$ & $\mathrm{~ms}$ \\
\hline $\mathrm{NaS}$ battery & $150-250$ & $90-230$ & $\begin{array}{c}3000-4000 € / \mathrm{kW} \\
400-600 € / \mathrm{kWh}\end{array}$ & $1500-5000$ & $75-90 \%$ & $10-20$ & commercial & $0,05 \%(20 \%)$ & $\mathrm{ms}$ \\
\hline Zebra battery & $94-140$ & $150-200$ & $\begin{array}{l}150-2600 € / \mathrm{kW} \\
550-750 € / \mathrm{kWh}\end{array}$ & $1000-7500$ & $84-95 \%$ & $10-15$ & commercial & $5 \%$ & $\mathrm{~ms}$ \\
\hline Flow battery & $10-85$ & $150-160$ & $\begin{array}{c}500-1300 € / \mathrm{kW} \\
100-1000 € / \mathrm{kWh}\end{array}$ & $2000-13000$ & $60-85 \%$ & $10-20$ & demo & $0,2-15 \%$ & $\mathrm{~ms}$ \\
\hline $\begin{array}{c}\text { Metal-air } \\
\text { battery }\end{array}$ & $150-5000$ & $100-150$ & $\begin{array}{l}80-1400 € / \mathrm{kW} \\
8-290 € / \mathrm{kWh} \\
\end{array}$ & $100-10000$ & $55-75 \%$ & - & $\mathrm{R} \& \mathrm{D}$, demo & - & $\mathrm{ms}$ \\
\hline Fuel cell & $800-10000$ & $5-800$ & $\begin{array}{c}1200-8500 € / \mathrm{kW} \\
5-610 € / \mathrm{kWh}\end{array}$ & $1000-20000$ & $\begin{array}{c}20-60 \% \\
(80 \% \\
\text { CHP) }\end{array}$ & $5-20$ & $\mathrm{R} \& \mathrm{D}$, demo & $0 \%$ & $5-10 \mathrm{~min}$ \\
\hline $\mathrm{H}_{2}$ & - & - & $\begin{array}{c}2000-5000 € / \mathrm{kW} \\
1-10 € / \mathrm{kWh}\end{array}$ & - & $20-40 \%$ & $5-30$ & $\mathrm{R} \& \mathrm{D}$, demo & - & $\mathrm{s}-\min$ \\
\hline TES & $80-250$ & $10-30$ & $\begin{array}{l}85-5000 € / \mathrm{kW} \\
0,1-100 € / \mathrm{kWh} \\
\end{array}$ & - & $30-60 \%$ & $5-30$ & $\begin{array}{c}\text { demo, } \\
\text { commercial }\end{array}$ & $0,05-1 \%$ & $\mathrm{~s}-\min$ \\
\hline
\end{tabular}

